\title{
Mechanisms for credit transfer of e-learning results within the framework of educational programs of higher education
}

\author{
Antoniy Shvindt ${ }^{1, *}$, and Ivan Nikanorov ${ }^{2}$ \\ ${ }^{1}$ Ministry of Education and Science of the Russian Federation, 125993 Moscow, Russian Federation \\ ${ }^{2}$ Federal Agency for Scientific Organizations, 119334 Moscow, Russian Federation
}

\begin{abstract}
The evolving mechanisms of e-learning leads to new challenges for traditional institutions of higher education. Different countries adopt various mechanisms for their harmonization and integration of the MOOC to the educational process. The Russian system of higher education is distinguished by rigidity of its standards and the requirements both to the educational process and to the results of education. This had significantly complicated the implementation of the MOOC in the educational programs of Russian universities. Changes in the legislation and the adoption of a strategy for the development of the digital educational environment in the Russian Federation has provided new opportunities to Russian universities in this regard. The article is devoted to various options, mechanisms and practices for the credit transfer of e-learning by Russian universities, which were revealed during the monitoring of their legal acts placed in the open sources.
\end{abstract}

\section{Introduction}

Increasing speed of technological progress requires increased flexibility and adaptability of the education system. A key issue that is relevant today to any country claiming technological leadership in the world is how to implement the trends in the national education system for personalization and individualization and to make it adaptable to a rapidly changing world. Different national educational systems offer their own solutions consistent with certain global challenges in one way or another. One of the most important of them has become global digitalization of economy and social services area, which requires rapid changes in the system of professional training of personnel and the environment of higher education [1], [2].

\footnotetext{
* Corresponding author: anshvindt@gmail.com
} 


\section{Global context}

One of the answers to this question was the emergence of OER - Open Educational Resources included by the United Nations in the document accepted in 2015 "Transforming our world: the 2030 Agenda for Sustainable Development". The implementation of its fourth goal of sustainable development (SDG 4) is entrusted to UNESCO. The key document determining the approaches to SDG 4 implementation is the Incheon Declaration accepted at the World Education Forum in 2015 and the "Framework for Action for the implementation of Sustainable Development Goal 4" confirmed in Paris on November,4, 2015 [3].

Also, the priorities identified in the 2016 Global Education Monitoring Report are worth mentioning, which are necessary to achieve SDG 4, including the need for the development of Open Educational Resources (OER) as an innovative method of knowledge sharing, contributing to high-quality education getting throughout life for everybody. To one of the most widespread and gaining popularity of OER during the last 5 years can be attributed Massive Open Online Courses (MOOC) [4]. According to Education International's research, the global education market volume is about $\$ 4.5-5$ trillion and in the coming years its possible growth is estimated to be $\$ 1-2$ trillion. The share of online education is about 3\%, which is $\$ 165$ billion. Due to the steady growth dynamics by 2023 , the digital part of the industry promises to overcome the mark of 240 billion US dollars, adding more than 5\% per year. The next largest region is Southeast Asia (the largest share here is China and India), with a market growth of about 17\%. Western Europe (6.8 billion US dollars) lags behind Eastern Europe (1.2 billion US dollars) yet, but it should be noted that Russia in this region is the driver of this direction with an average annual growth of $17-25 \%$ [5].

\section{Russian development of e-learning environment}

However, in Russian MOOC-segment of EdTech factors are worth noting that hamper its development in formal education [6]. Among such factors it is necessary to note a lack of trust in distance education, yet unformed system of implementing individual educational trajectories in general, in particular - the introduction of the MOOC to the implementation of basic educational programs, the lack of elaborated mechanisms for cost recovery as an individual student in the case of developing an online course on an external platform (in another educational organization), and the acquisition of MOOC by one educational organization from another at the expense of the federal budget, in accordance with the control figures for admission as a state task for the implementation of higher professional education programs, the disorganization of mechanisms of conducting state accreditation expertise and the implementation of state supervision and control in the field of education, taking into account the integration of MOOCs established in other educational and (or) other organizations, in the basic educational programs.

Summarizing these factors, we can say that they relate to the regulatory and administrative barriers that exist at two levels: bylaws adopted by federal government bodies and local normative legal acts approved at the level of each educational organization. Let is consider the issue related to federal legislation and bylaws providing the possibility of credit transfer of the taken online courses as part of the module or as a whole discipline in the framework of mastering the basic educational programs of higher education by students.

It is important to note here that the key normative legal act of the Russian Federation in the field of education is the Federal Law No.273-FZ "On Education in the Russian Federation" presupposes, on the one hand, the academic rights exist of students to be certified by an organization that carries out educational activities, mastering students' 
subjects, courses, disciplines (modules), practice, additional educational programs in other organizations that carry out educational activities, and on the other hand, the educational organization has autonomy, which is understood as independence in the implementation of educational, scientific, administrative, financial and economic activities, the development and adoption of local regulations, as well as its competence includes the right to exercise current monitoring of academic performance and intermediate certification of students, the establishment of its forms and periodicity.

\section{Normative grounds for the implementation of e-learning in the system of higher education in Russia}

Integration of statutory rights of students for credit transfer and educational organizations for their autonomy is established in paragraph 41 of the Order of the Ministry of Education and Science of Russia No. 301 of April 5, 2017, which was enacted on September 1, 2017, as well as in paragraph 8 of the Order of the Ministry of Education and Science No. 816 of August 23, 2017. In connection with the right of educational organizations to establish the procedure and forms for the studies passing in individual disciplines and (or) individual practices that have been mastered (passed) by students in obtaining secondary vocational education and (or) higher education, as well as additional education interest analysis of the local regulatory legal acts adopted by educational organizations, which provide for the relevant procedure. In accordance with subparagraph e) of paragraph 2 of art. 29 of the Law on Education in the Russian Federation, educational organizations ensure openness and accessibility via the publication of copies of local regulatory legal acts on the basic issues of organization and implementation of educational activities, including regulating the procedure and forms for the exercise of noted right of students for credit transfer on their official website.

\section{Variability of practices of implementation by universities of e-learning in educational programs}

Analysing local normative legal acts from open sources of 287 educational organizations, it is possible to single out four main models that are implemented today in Russian universities. The first model - the educational organization preliminarily establishes a list of platforms containing online courses or a list of specific online courses (created in Russia or in other countries), and the document on the passage is passed by default, without additional tests. This model is implemented by $37 \%$ of organizations. The second model before the beginning of the semester the educational organization accepts the applications from students with the list of online courses planned for passage in the current semester, forms lists of such students, and during the intermediate certification conducts own tests to confirm the knowledge received on the online course. This model is implemented by $21 \%$ of organizations. Such tests are fixed in the local normative legal acts of universities as an examination, differentiated credit, offset or interview. The third model - the educational organization transfers credits for the disciplines, including ones that mastered by the student in the form of an online course, only during the procedure of transfer from one educational organization to another, or the mastering of an educational program on an individual curriculum. This model is implemented by $6 \%$ of organizations. It should be noted that $7 \%$ of educational organizations do not provide the possibility of credit transfer of the passage of external open online courses, but only their own ones and they can be attributed to the fourth model. Another $29 \%$ of universities do not have local normative legal documentation, which provides an appropriate procedure for credit transfer. 


\section{Conclusions}

Among the reasons why educational organizations today do not fully use the tools of modern educational technologies, such as OER as a whole and MOOC, as the most actively developing forms of their implementation, one can note first of all normative barriers, as well as distrust of quality and conservatism, As a property of any educational system as a whole. At the same time, the implementation of the norms of the Law on Education in the part of the right of students for credit transfer, enforcing secondary regulatory legal acts accepted by the Ministry of Education and Science of the Russian Federation in 2017, the appearance of online courses in these documents and the process of changing of local regulatory legal framework of educational organizations reduce administrative and regulatory barriers for active development of Russian market EdTech in the formal education sector and create opportunities for Russia to implement personalization and individualization of educational trajectories of students [10], as well as to implement to goal 4 in the field of sustainable development "Ensure inclusive and quality education for all and promote lifelong learning", which will allow to unlock fully the potential of human capital.

\section{References}

1. K. Donnelly, S. Rizvi, L. Summers, An avalanche is coming: Higher education and the revolution ahead Research raport (The Institute for Public Policy Research, London, 2013)

2. L. Shultz, M. Viczko, Lynette Shultz Assembling and Governing the Higher Education Institution. Democracy, Social Justice and Leadership in Global Higher Education (Palgrave Macmillan, UK, 2016) DOI 10.1057/978-1-137-52261-0

3. "Transforming our world: the 2030 Agenda for Sustainable Development" Electronic resource:

https://documents-dds-ny.un.org/doc/UNDOC/GEN/N15/291/89/PDF/N1529189.pdf Open Element

4. Ichon Declaration and Framework for Action for the implementation of Sustainable Development Goal 4 Electronic resource: http://unesdoc.unesco.org/images/0024/002456/245656R.pdf

5. «Research of the Russian market of online education and educational technologies» Electronic resource: http://edumarket.digital.

6. M. Carnoy, Y. Kuzminov Voprosy obrazovaniya (Educational Studies), 3, 8 [In Russian] DOI: 10.17323/1814-9545-2015-3-8-43.

7. K. Mertins, V. Ivanova, M. Abdrashitova, D. Isaeva MATEC Web Conf. 48, 06005 (2016) 